\title{
LITERASI PRODUK PERBANKAN SYARIAH BAGI GURU PONDOK PESANTREN DI KOTA PEKANBARU
}

\section{LITERATION OF SHARIA BANKING PRODUCTS FOR PONDOK PESANTREN TEACHERS IN PEKANBARU CITY}

\author{
Putri Nuraini' ${ }^{1}$, Mufti Hasan Alfani ${ }^{2}$, Zulfadli Hamzah ${ }^{3}$ \\ Universitas Islam Riau ${ }^{1,2,3}$ \\ putrinuraini@fis.uir.ac.id ${ }^{1}$
}

\begin{abstract}
Literacy is related to a person's competence and knowledge about a particular discipline or area. Islamic banking literacy is a person's understanding of Islamic banking products and his ability to make financial decisions effectively. Thus, Islamic banking product literacy shows a person's level of understanding comprehensively. This study aims to determine the literacy of Islamic banking products in Islamic boarding school teachers in Pekanbaru City, so that later Islamic boarding school teachers will not only know but also be able to access and use existing products in Islamic banking. The formulation of the problem in this study is how the literacy of Islamic banking products for Islamic boarding school teachers in Pekanbaru City?. The purpose of this study was to determine the literacy of Islamic banking products in Islamic boarding school teachers in Pekanbaru City. This research is a field research (field research). The population in this study were teachers of Islamic boarding schools in Pekanbaru City, the sample in this study amounted to 87 people with the sampling technique using purposive sampling technique. The data collection method is by distributing questionnaires, interviews and documentation. Data analysis is descriptive in nature, data are grouped and described according to their type and analyzed using qualitative analysis, then presented in tabular form and equipped with explanations. The results of this study indicate that the literacy of Islamic banking products for Islamic boarding school teachers in the city of Pekanbaru is classified as sufficient literate, this can be seen from the large percentage of respondents' answers of 43.34\%, meaning that literacy of Islamic banking products for Islamic boarding school teachers in Pekanbaru city has not reached the expected target. . This indicates that the teacher's response to Islamic banking products is "good" but the use of Islamic banking products is still minimal in the Islamic boarding school teachers, especially in the city of Pekanbaru.
\end{abstract}

Keywords: Literacy, Islamic Banking Products, Islamic Boarding

\begin{abstract}
ABSTRAK
Literasi terkait dengan kompetensi dan pengetahuan seseorang tentang disiplin ilmu atau area tertentu. Literasi perbankan syariah merupakan pemahaman seseorang tentang produk perbankan syariah dan kemampuannya untuk mengambil keputusan keuangan secara efektif. Dengan demikian, literasi produk perbankan syariah menunjukkan tingkat pemahaman seseorang secara komprehensif. Penelitian ini bertujuan untuk mengetahui literasi produk perbankan syariah pada guru pondok pesantren di Kota Pekanbaru, agar nantinya guru pondok pesantren tidak hanya mengetahui tetapi juga mampu mengakses dan menggunakan produk-produk yang ada di perbankan syariah. Rumusan masalah
\end{abstract}


dalam penelitian ini adalah bagaimana literasi produk perbankan syariah bagi guru pondok pesantren di Kota Pekanbaru?. Tujuan penelitian ini untuk mengetahui literasi produk perbankan syariah pada guru pondok pesantren di Kota Pekanbaru. Penelitian ini merupakan penelitian lapangan (field research). Populasi dalam penelitian ini adalah guru pondok pesantren yang berada di Kota Pekanbaru, sampel dalam penelitian ini berjumlah 87 orang dengan teknik pengambilan sampel menggunakan teknik purposive sampling. Adapun metode pengumpulan data dengan melakukan penyebaran angket, wawancara dan dokumentasi. Analisa data bersifat deskriptif, data dikelompokkan dan diuraikan sesuai dengan jenisnya dan dianalisis dengan menggunakan analisis kualitatif, kemudian disajikan dalam bentuk tabel serta dilengkapi dengan penjelasan. Hasil penelitian ini menunjukkan bahwa literasi produk perbankan syariah bagi guru pondok pesantren di kota Pekanbaru tergolong kedalam sufficient literate, hal ini terlihat dari besarnya persentase jawaban responden sebesar $43.34 \%$, artinya literasi produk perbankan syariah bagi guru pondok pesantren di kota Pekanbaru belum mencapai target yang diharapkan. Hal ini menandakan bahwa respon guru terhadap produk perbankan syariah "baik" namun masih minimnya penggunaaan produk-produk perbankan syariah di lingkungan guru pondok pesantren khususnya di kota Pekanbaru.

Kata Kunci : Literasi, Produk Perbankan Syariah, Pondok Pesantren, Kota Pekanbaru

\section{PENDAHULUAN}

Literasi produk perbankan syariah merupakan hal yang sangat penting dipahami dan dimiliki oleh seluruh lapisan masyarakat pada zaman modern ini. Literasi keuangan dapat didefinisikan sebagai pengetahuan seseorang mengenai keuangan dan cara mengelolanya yang bertujuan untuk mencapai kesejahteraan (Rita, 2019).

Literasi keuangan merupakan sebuah proses serta kegiatan dalam rangka meningkatkan pengetahuan, kesadaran, keyakinan, kemampuan dan keterampilan mengelola keuangan, sehingga masyarakat dapat memanfaatkan layanan jasa keuangan (konvensional maupun syariah) demi mensejahterakan dan mewaspadai keadaan atau kondisi keuangan dimasa yang akan datang (Giesler, 2014).

Otoritas Jasa Keuangan berusaha meningkatkan literasi keuangan melalui program blue print Strategi Nasional Keuangan Inklusif (SNLKI) yang diluncurkan pada tahun 2013. Berdasarkan survey yang pernah dilakukan Otorisasi Jasa Keuangan (OJK) pada tahun 2013 tentang tingkat literasi keuangan penduduk Indonesia yang terbagi menjadi empat kategori, yaitu well literate, sufficient literate, less literate dan not literate (Muhammad, 2018).

Pondok pesantren merupakan institusi atau lembaga pendidikan yang memiliki potensi besar untuk mengembangkan ekonomi syariah, khususnya di bidang keuangan syariah serta dapat meningkatkan market share keuangan syariah nasional, khususnya perbankan syariah. Sampai dengan saat ini, market share perbankan syariah Nasional secara keseluruhan masih dibawah 5\%. Akan tetapi, apabila dilihat dari setiap jenis produk syariah, hingga akhir Desember 2016 terdapat bebeapa produk perbankan syariah yang market share nya diatas 5\%, antara lain aset perbankan syariah sebesar 5,33\% dari seluruh aset perbankan (www.ojk.go.id).

Pada tahun 2019 di Kota Pekanbaru terdapat 20 pondok pesantren dengan jumlah guru sebanyak 617 orang (Kemenag Kota Pekanbaru, 2019). Hal ini tergolong besar jika diperuntukkan 
bagi sebuah potensi pengembangan dan peningkatan market share keuangan syariah di Kota Pekanbaru. Pemahaman Fatwa MUI (Majelis Ulama Indonesia) Tahun 2004 Tentang Hukum Bunga Bank yang sudah lama dikeluarkan seharusnya dapat lebih dipahami secara merata oleh para guru yang mengajar di pondok pesantren.

Masih minimnya penggunaaan produk-produk perbankan syariah dilingkungan guru pondok pesantren, hal ini menjadi perhatian mengingat pondok pesantren merupakan tempat yang strategis untuk pengembangan ekonomi, sehingga nantinya perbankan syariah bisa ikut andil dalam mendorong perekonomian di lingkungan sekitar pondok pesantren. Literasi produk perbankan syariah menjadi pembahasan dalam penelitian ini lebih mengarah pada pengetahuan tentang perbankan syariah serta penggunaan produk perbankan syariah. Aspek-aspek yang dibahas dalam penelitian ini adalah aspek pengetahuan, keyakinan dan proses/aktivitas.

Literasi adalah istilah umum yang merujuk kepada seperangkat kemampuan dan keterampilan individu dalam membaca, menulis, berbicara, menghitung dan memecahkan masalah pada tingkat keahlian tertentu yang diperlukan dalam kehidupan sehari-hari (KBBI, 2018). Remund, (2010) menjelaskan bahwa istilah literasi keuangan, pengetahuan keuangan, dan kapasitas keuangan sering digunakan secara bergantian. Literasi keuangan didefinisikan sebagai terdiri dua elemen kunci seberapa baik seorang individu dapat memahami informasi keuangan dan seberapa baik seorang individu dapat menggunakan informasi keuangan untuk mengelola keuangan pribadinya baik dalam pengambilan keputusan jangka pendek dan perencanaan keuangan jangka Panjang (Tina, 2016).
Otoritas Jasa Keuangan menyatakan bahwa secara defenisi literasi diartikan sebagai kemampuan memahami, jadi literasi keuangan adalah kemampuan mengelola dana yang dimiliki agar berkembang dan hidup bisa lebih sejahtera dimasa yang akan datang, misi penting dari program literasi keuangan adalah untuk melakukan edukasi dibidang keuangan kepada masyarakat Indonesia agar dapat mengelola keuangan secara cerdas, supaya rendahnya pengetahuan tentang industri keuangan dapat diatasi dan masyarakat tidak mudah tertipu pada produk-produk investasi yang menawarkan keuntungan tinggi dalam jangka pendek tanpa mempertimbangkan resikonya. Jadi dari definisi-definisi tersebut dapat dipahami bahwa literasi keuangan merupakan salah satu kebutuhan dasar bagi setiap orang agar terhindar dari masalah keuangan.

Setiap orang memiliki pengetahuan yang memadai untuk merencanakan dan mengatur keuangan pribadinya dengan tujuan untuk mencapai kesejahteraan. Tingkat literasi yang memadai dapat meningkatkan kehidupan yang lebih baik, terhindar dari kesulitan keuangan. Kesulitan keuangan tidak hanya dikarenakan rendahnya pendapatan seseorang, kesulitan keuangan yang dialami oleh seseorang bukan dari pendapatan semata, tetapi bisa juga disebabkan karena kesalahan manajemen (mismanagement) keuangan (Krishna, 2010).

Menurut Undang-Undang Nomor 21 Tahun 2008 Tentang Perbankan Syariah, perbankan syariah adalah segala sesuatu yang berhubungan dengan Bank Umum Syariah dan Unit Usaha Syariah, mencakup lembaga, kegiatan usaha, serta cara dan proses dalam melaksanakan kegiatan usahanya. Bank sayriah adalah bank yang menjalankan kegiatan usahanya berdasarkan prinsip syariah dan 
menurut jenisnya terdiri dari Bank Umum Syariah (BUS) dan Bank Pembiayaan Rakyat Syariah (BPRS). Dalam perbankan saat ini sudah ada perbankan yang menjalankan operasional dan bisnisnya sesuai dengan syariat Islam yaitu Perbankan Syariah. Perbankan Syariah merupakan suatu sistem perbankan yang dijalankan berdasarkan prinsip dan hukum Islam dengan berpedoman kepada al-Quran dan asSunnah. Dalam praktiknya, perbankan syariah melarang bunga serta melarang melakukan investasi pada usaha yang haram

$\begin{array}{cccr}\text { Akad dan } & \text { aspek legalitas } \\ \text { merupakan kunci } & \text { utama yang }\end{array}$
membedakan bank syariah dengan bank konvensional lainnya. bank syariah melihat dari "innamal a'malu bin niat", sesungguhnya setiap amalan begantung pada niat. Dalam hal ini bergantung pada aqad nya, seperti bagi hasil, jual beli atau sewa menyewa. tidak ada unsur riba yang diharamkan. Menurut Antonio (2001), setiap akad dalam perbankan syariah, baik dalam hal barang, pelaku transaksi, maupun ketentuan lainnya, harus memenuhi ketentuan akad yaitu rukun (penjual, pembeli, barang, harga dan akad) dan syarat akad yakni:

1. Barang dan jasa harus halal sehingga transaksi atas barang dan jasa yang haram menjadi batal demi hukum syariah;

2. Harga barang dan jasa arus jelas;

3. Tempat penyerahan (delivery) harus jelas karena akan berdampak pada biaya transportasi.

4. Barang yang ditransaksikan harus ssepenuhnya dalam kepemilikan.

5. Tidak boleh menjual sesuatu yang belum dimiliki atau dikuasai seperti yang terjadi pada transaksi short shale dalam pasar modal

\section{METODE PENELITIAN}

Penelitian ini merupakan penelitian lapangan (field research). Jenis penelitian yang digunakan dalam penelitian ini adalah jenis penelitian deskriptif. Jenis penelitian deskriptif adalah jenis penelitian yang disusun dalam rangka memberikan gambaran secara sistematis tentang informasi ilmiah yang berasal dari subjek atau objek penelitian. Penelitian ini dilaksanakan pada 9 (sembilan) pondok pesantren yang ada di kota Pekanbaru Provinsi Riau. Adapun yang menjadi subjek penelitian ini adalah seluruh guru pada 9 (sembilan) pondok pesantren yang ada di Kota Pekanbaru. Sedangkan objek dalam penelitian ini adalah literasi produk perbankan syariah. Penulis memilih lokasi penelitian pada pondok pesantren di Kota Pekanbaru karena pondok pesantren merupakan institusi atau lembaga pendidikan yang memiliki potensi besar untuk mengembangkan ekonomi syariah, khususnya di bidang keuangan syariah serta dapat meningkatkan market share keuangan syariah nasional, khususnya perbankan syariah.

Adapun sebagai populasi dalam penelitian ini guru pada 9 (Sembilan) pondok pesantren di Kota Pekanbaru tahun 2020 yang berjumlah 617 orang. Sampel adalah bagian dari jumlah dan karakteristik yang dimiliki oleh populasi tersebut. Dari jumlah populasi tersebut, maka penulis mengambil sampel dengan menggunakan teknik purposive sampling. Adapun jumlah sampel ditentukan dengan menggunakan rumus slovin, sebagai berikut:

$$
\mathrm{n}=\frac{\mathrm{N}}{1+\mathrm{N} \cdot e^{2}}
$$

Keterangan : 
n : ukuran sampel

$\mathrm{N}$ : populasi

e : error, persentase kelonggaran kesalahan penetapan sampel penelitian (dalam hal ini ditetapkan sebesar $10 \%)$.

Berdasarkan rumusan diatas dapat dihitung ukuran sample sebagai berikut :

$$
\begin{gathered}
\mathrm{n}=\frac{617}{1+617(0,1)^{2}} \\
\mathrm{n}=\frac{617}{1+6,17} \\
\mathrm{n}=\frac{617}{7,17} \\
\mathrm{n}=86,05=87 \text { responden }
\end{gathered}
$$

Jadi dalam penelitian ini ukuran sampelnya dibulatkan menjadi 87 orang responden yang terlihat jelas pada tabel 1 tentang distribusi unit sampel penelitian dibawah ini :

Tabel 1 Distribusi Unit Sampel Penelitian

\begin{tabular}{clc}
\hline No. & Pondok Pesantren & Unit Sampel \\
\hline 1 & $\begin{array}{l}\text { Pondok Modern Al- } \\
\text { Kautsar }\end{array}$ & 10 Orang \\
\hline 2 & $\begin{array}{l}\text { Pondok Pesantren } \\
\text { Al-Munawarah }\end{array}$ & 10 Orang \\
\hline 3 & $\begin{array}{l}\text { Pondok Pesantren } \\
\text { Al-Ikhwan }\end{array}$ & 10 Orang \\
\hline 4 & $\begin{array}{l}\text { Pondok Pesantren } \\
\text { Darul Quran }\end{array}$ & 10 Orang \\
\hline 5 & $\begin{array}{l}\text { Pondok Pesantren } \\
\text { Diniyah Putri }\end{array}$ & 10 Orang \\
\hline 6 & $\begin{array}{l}\text { Pondok Pesantren } \\
\text { Darel Hikmah }\end{array}$ & 10 Orang \\
\hline 7 & $\begin{array}{l}\text { Pondok Pesantren } \\
\text { Ummul Quro }\end{array}$ & 9 Orang \\
\hline 8 & $\begin{array}{l}\text { Pondok Pesantren } \\
\text { Al-Furqan }\end{array}$ & 9 Orang \\
\hline 9 & $\begin{array}{l}\text { Pondok Pesantren } \\
\text { Hidayatullah }\end{array}$ & 9 Orang \\
\hline & Jumlah & $\mathbf{8 7 ~ O r a n g}$ \\
\hline
\end{tabular}

Sumber: Data Olahan, 2020

Teknik Pengumpulan Data Angket
Pertanyaan yang dirancang untuk mengetahui literasi produk perbankan syariah bagi guru pondok pesantren di Kota Pekanbaru.

\section{Wawancara}

Merupakan kegiatan tanya jawab secara lisan antara dua orang atau lebih secara langsung atau proses memperoleh keterangan untuk tujuan penelitian dengan cara tanya jawab sambil bertatap muka antara pewawancara dan informan. Digunakan untuk mendapatkan informasi melalui guru tentang literasi produk perbankan syariah sebagai tambahan untuk mendukung data penelitian.

\section{Dokumentasi}

Dokumentasi adalah untuk mengumpulkan data sekunder dari berbagai sumber, baik secara pribadi maupun kelembagaan untuk memperoleh data langsung dari tempat penelitian, meliputi peraturan-peraturan, laporan keuangan, struktur organisasi, data relevan dengan penelitian.

\section{Metode dan Teknik Analisa Data}

Setelah data berhasil

dikumpulkan, selanjutnya penulis menganalisa data tersebut dengan menggunakan metode deskriptif kualitatif, yaitu menganalisa data atas dasar - dasar persamaan jenis data, dan fenomena sosial yang tengah diteliti. Metode deskriptif digunakan setelah data yang diperlukan diperoleh, lalu data tersebut dikelompokkan dan diuraikan sesuai dengan jenisnya dan dianalisa dengan menggunakan analisis kualitatif, kemudian disajikan dalam bentuk tabel yang dilengkapi dengan penjelasan.

Teknik analisis data dalam penelitian ini dilakukan secara bertahap, tahap-tahap dalam penelitian ini adalah sebagai berikut:

1. Penyunting (editing), Penyunting adalah kegiatan yang dilaksanakan 
setelah peneliti selesai menghimpun data dilapangan. Kegiatan ini menjadi penting karena kenyataannya data yang terhimpun kadangkala belum memenuhi harapan peneliti, ada diantaranya kurang atau terlewatkan, berlebihan atau terlupakan.

2. Pengkodean (coding), Pengkodean adalah memberikan tanda dengan tujuan adalah untuk mengetahui mana data yang sama atau tidak.

3. Pembeberan (tabulating), Pembeberan adalah bagian terakhir dari pengolahan data maksud dari

4. tabulasi adalah memasukkan data pada tabel tertentu dan mengatur angkaangka serta menghitungnya.

\section{HASIL DAN PEMBAHASAN}

Berdasarkan hasil rekapitulasi data identitas responden dapat dilihat bahwa keseluruhan responden berjumlah 87 orang berdasarkan indikator diataranya: Pertama, responden berdasarkan Jenis Kelamin, menunjukkan bahwa responden yang berjenis kelamin laki-laki lebih dominan yaitu berjumlah 55 orang atau sebesar 63,22\%. Sedangkan responden berjenis kelamin perempuan hanya berjumlah 32 orang atau sebesar 36,78\%. Kedua, responden berdasarkan tingkat Usia, terlihat jelas tingkat usia 20 - 30 tahun lebih banyak, yaitu berjumlah 41 orang atau dengan persentase sebesar 47,12\%. Kemudian diikuti dengan tingkat usia $<20$ dan $30-$ 40 sebanyak 17 orang stau sebesar $19,54 \%$ dan terakhir tingkat usia $>40$ berjumlah 12 orang atau sebesar 13,80\%.

Ketiga, responden berdasarkan Pendapatan per Bulan, menunjukkan bahwasanya pendapatan responden yang terbanyak pada penghasilan 2 juta -3 juta yaitu berjumlah 65 orang atau sebesar 74,71\%. Keempat, responden berdasarkan Pendidikan Terakhir, menunjukkan bahwa pendidikan responden paling dominan berada pada pendidikan S1 sebanyak 51 orang atau $58,62 \%$ dan yang terkecil yaitu pada tingkat pendidikan Akademi (D1/D2/D3) dengan jumlah 5 orang atau 5,75\%.

\section{Analisis Data \\ Pengetahuan Ekonomi Syariah}

Berdasarkan hasil uji tanggapan responden dapat dilihat bahwa tanggapan responden mengenai aspek pengetahuan ekonomi syariah memperoleh respon "Sangat Setuju" oleh guru pondok pesantren dengan jumlah persentase sebesar $63,98 \%$. Item pernyataan yang dominan terdapat pada pernyataan "Bank syariah memiliki produk produk simpanan dan pembiayaan dengan prinsip dan akad yang berbeda - beda sesuai dengan kebutuhan nasabah".

\section{Keyakinan \& Pemahaman Perbankan Syariah (Produk-produk Perbankan Syariah)}

Berdasarkan hasil uji tanggapan responden dapat dilihat bahwa tanggapan responden mengenai aspek Keyakinan \& Pemahaman Perbankan Syariah (Produkproduk Perbankan Syariah) lebih dominan pada jawaban "Setuju" guru pondok pesantren dengan jumlah persentase sebesar 49,26\%. Adapun yang menjadi unsur pokok jawaban responden pada item pernyatan "Produk-produk yang diberikan oleh bank syariah sama saja dengan produk dari bank konvesional" berjumlah 34 orang artinya guru pondok pesantren masih menganggap bahwa produkproduk yang ditawarkan perbankan syariah sama saja dengan konvensional, padahal produk perbankan syariah berbeda dengan perbankan konvensional. Hal yang membedakannya adalah terletak pada sistem dan akadnya.

\section{Proses atau Aktivitas Sosialisasi}

Berdasarkan hasil uji tanggapan responden dapat dilihat bahwa tanggapan responden mengenai aspek proses atau 
aktivitas sosialisasi produk perbankan syariah memperoleh respon "Setuju" oleh guru pondok pesantren dengan jumlah persentase sebesar $43,68 \%$ yang terdapat pada pernyataan "Saya memahami dan mengetahui lembaga keuangan syariah melalui informasi media masa".

Penelitian ini membahsan tentang literasi produk perbankan syariah bagi guru pondok pesantren di kota Pekanbaru. Dari hasil perhitungan di atas diketahui bahwa Literasi Produk Perbankan Syariah Terhadap Guru Pondok Pesantren di Kota Pekanbaru berdasarkan Aspek "Pengetahuan Ekonomi Syariah" tanggapan responden mengenai aspek pengetahuan ekonomi syariah memperoleh respon "Sangat Setuju" oleh guru pondok pesantren dengan jumlah persentase sebesar $63,98 \%$. Item pernyataan yang dominan terdapat pada pernyataan "Bank syariah memiliki produk produk simpanan dan pembiayaan dengan prinsip dan akad yang berbeda - beda sesuai dengan kebutuhan nasabah.

Jadi dapat dikatan bahwa guru pondok pesantren yang ada di Kota Pekanbaru mengetahui pengetahuan dasar mengenai Ekonomi Syariah dan sangat setuju dengan sistem yang diterapkan pada Perbankan Syariah. Artinya, pada pemahaman guru pondok pesantren dari aspek pengetahuan ekonomi syariah masuk kedalam kategori well literate yaitu tingkatan ini dianggap memiliki pengetahuan dan keyakinan tentang lembaga jasa keuangan serta produk jasa keuangan, termasuk fitur, manfaat dan risiko, hak dan kewajiban terkait produk dan jasa keuangan, serta memiliki keterampilan dalam menggunakan produk dan jasa keuangan. Berdasarkan wawancara penulis dengan salah satu Pimpinan Pondok Bapak Ali Muhklisin, M.Pd., (PM Al-Kautsar, 11 Juli 2020) mengatakan bahwa guru dipondok pesantren khususnya Pondok
Modern Al-Kautsar mengetahui produk dan sistem di perbankan syariah, karena rata-rata guru berpendidikan S1 ekonomi syariah dan dalam sistem pembayaran gaji pondok modern ini telah bekerjasama dengan salah satu perbankan syariah yang ada di Kota Pekanbaru.

Pada aspek "pengetahuan ekonomi keyakinan \& pemahaman perbankan syariah" (produk-produk perbankan syariah) lebih dominan pada jawaban "Setuju" guru pondok pesantren dengan jumlah persentase sebesar 49,26\%. Adapun yang menjadi unsur pokok jawaban responden pada item pernyatan "Produk-produk yang diberikan oleh bank syariah sama saja dengan produk dari bank konvesional" berjumlah 34 orang artinya guru pondok pesantren masih menganggap bahwa produk-produk yang ditawarkan perbankan syariah sama saja dengan konvensional, padahal produk perbankan syariah berbeda dengan perbankan konvensional, hal yang membedakan adalah terletak pada sistem dan akadnya. Jadi dapat dikatakan bahwa guru pondok pesantren yang ada di kota Pekanbaru hanya sebatas memahami dan meyakini produk produk yang ada di Perbankan Syariah dan tidak sepenuhnya mengetahui perbedaan dengan perbankan konvensional begitu pula dengan sistem yang terdapat didalamnya. Berdasarkan wawancara penulis dengan salah satu guru pondok pesantren Ibu Junaida, S.Pd. (PP Al-Munawarah, 14 Juli 2020) mengatakan bahwa belum sepenuhnya mengguakan produk perbankan syariah dalam bertransaksi, baik tabungan maupun lainnya, mereka hanya sebatas memahami dan meyakini saja. Artinya, pada pemahaman guru pondok pesantren dari aspek pengetahuan ekonomi keyakinan \& pemahaman perbankan syariah (produk-produk perbankan syariah) masuk kedalam kategori sufficient literate, yaitu pada tingkatan ini 
guru-guru hanya sebatas memiliki pengetahuan dan keyakinan tentang lembaga jasa keuangan serta produk dan jasa keuangan, termasuk fitur, manfaat dan risiko, hak dan kewajiban terkait produk dan jasa keuangan syariah.

Literasi guru pondok pesantren terhadap aspek proses atau aktivitas sosialisasi, dapat dilihat bahwa tanggapan responden mengenai aspek proses atau aktivitas sosialisasi produk perbankan syariah memperoleh respon "Setuju" oleh guru pondok pesantren dengan jumlah persentase sebesar $43,68 \%$ yang terdapat pada pernyataan "Saya memahami dan mengetahui lembaga keuangan syariah melalui informasi media masa". Kemudian, jawaban reponden juga banyak "Ragu-ragu" yakni dengan persentase sebesar $28.74 \%$, hal ini berarti sebagian besar guru pondok pesantren di kota Pekanbaru masih belum mendapatkan informasi literasi dan edukasi secara optimal mengenai produkproduk perbankan syariah (wawancara dengan Ibu Vony, SH pegawai Kemenag Kota Pekanbaru Bagian PD Pontren). Jadi dapat dikatakan bahwa guru pondok pesantren hanya mengetahui produk perbankan syariah melalui media masa saja dan belum sepenuhnya mendapatkan informasi tentang produk perbankan syariah melalui kegiatankegiatan edukasi dan seminar yang dilakukan oleh lembaga terkait. Pemahaman dari aspek proses atau aktivitas sosialisasi masuk kedalam kategori less literate, hanya memiliki pengetahuan tentang lembaga jasa keuangan, produk dan jasa keuangan melalui media masa saja kemudian produk dan jasa yang diketahui oleh guru pondok pesantren hanyalah sebatas produk dan jasa yang mereka gunakan saja.

Berdasarkan hasil analisis data rekapitulasi secara keseluruhan menyatakan bahwa literasi produk perbankan syariah bagi guru pondok pesantren di kota Pekanbaru tergolong kedalam sufficient literate, hal ini terlihat dari besarnya persentase jawaban responden yang menyatakan "setuju" sebesar 43.34\%. Dari survey yang dilakukan Otorisasi Jasa Keuangan (OJK) pada tahun 2013 tentang tingkat literasi keuangan pada tingkat sufficient literate mencapai $75,69 \%$, artinya literasi produk perbankan syariah bagi guru pondok pesantren di kota Pekanbaru belum mencapai target yang diharapkan. Hal ini menandakan bahwa respon guru terhadap produk perbankan syariah "baik" namun masih minimnya penggunaaan produkproduk perbankan syariah di lingkungan guru pondok pesantren, hal ini menjadi perhatian yang penting karena pondok pesantren merupakan tempat yang strategis untuk pengembangan ekonomi syariah, sehingga nantinya perbankan syariah bisa ikut andil dalam mendorong perekonomian di lingkungan pondok pesantren khususnya di kota Pekanbaru.

\section{PENUTUP \\ Kesimpulan}

Berdasarkan hasil penelitian dapat disimpulkan bahwa tingkat literasi produk perbankan syariah bagi guru pondok pesantren di kota Pekanbaru dilihat dari: Pertama, pemahaman dari aspek pengetahuan ekonomi syariah masuk kedalam kategori well literate. Kedua, pemahaman dari aspek keyakinan \& pemahaman perbankan syariah (produk-produk perbankan syariah) masuk kedalam kategori sufficient literate. Ketiga, pemahaman dari aspek proses atau aktivitas sosialisasi masuk kedalam kategori less literate.

\section{Saran}

Berdasarkan hasil analisis data rekapitulasi secara keseluruhan menyatakan bahwa literasi produk perbankan syariah bagi guru pondok 
pesantren di kota Pekanbaru tergolong kedalam sufficient literate atau respon guru terhadap produk perbankan syariah tergolong "baik" namun masih minimnya penggunaaan produk-produk perbankan syariah di lingkungan guru pondok pesantren di kota Pekanbaru.

\section{DAFTAR PUSTAKA}

Antonio, M., S. (2001), Bank Syariah Dari teori ke Praktik, Jakarta: Gema Insani.

Fatwa Dewan Syariah Nasional MUI No.01/DSN-MUI/IV/2000 tentang Giro.

Fatwa Dewan Syariah Nasional MUI No.02/DSN-MUI/IV/2000 tentang Tabungan.

Fatwa Dewan Syariah Nasional MUI No.03/DSN-MUI/IV/2000 tentang Deposito.

Giesler, M., \& Veresiu, E. (2014). Creating the responsible consumer: Moralistic governance regimes and consumer subjectivity. Journal of Consumer Research, 41(3):840-857.

Kamus Besar Bahasa Indonesia, (2018), Badan Pengembangan dan Pembinaan Bahasa.
Krishna, A., Rofaida, R., \& Sari, M. (2010). Analisis Tingkat Literasi Keuangan di Kalangan Mahasiswa dan Faktor-Faktor yang Memepengaruhinya.

Muhammad, K., A. (2018). Literasi Keuangan Syariah dan Pondok Pesantren (Studi Kasus Pondok Modern Asy-Syifa Balikpapan). Jurnal Ekonomi Islam. 9(2):191210.

Otoritas Jasa Keuangan, Siaran Pers, OJK. (2014). Indeks Literasi dan Keuangan Inklusi Keuangan dalam http://www.ojk.go.id.

Remund, D., L. (2010). Financial Literacy Explicated: The Case for a Clearer Definition in an Increasingly Complex Economy. The Journal of Consumer Affairs, 44(2).

Rita (2019). Literasi Keuangan Syariah di Kalangan Pondok Pesantren. Cirebon. CV. ELSI PRO

Tina, H. (2016), Financial Literacy and the Limits of Financial Decision Making, Springer: Switzerland Management, 1(3):191-209. 